\title{
Contributions of dust and biomass burning to aerosols at a Colorado mountain-top site
}

\author{
A. G. Hallar ${ }^{1}$, R. Petersen ${ }^{1}$, E. Andrews ${ }^{2,3}$, J. Michalsky ${ }^{2,3}$, I. B. McCubbin ${ }^{1}$, and J. A. Ogren ${ }^{2}$ \\ ${ }^{1}$ Storm Peak Laboratory, Desert Research Institute, Steamboat Springs, CO, USA \\ ${ }^{2}$ NOAA Earth System Research Laboratory, Boulder, CO, USA \\ ${ }^{3}$ Cooperative Institute for Research in Environmental Sciences, University of Colorado, Boulder, CO, USA
}

Correspondence to: A. G. Hallar (ghallar@dri.edu)

Received: 10 July 2015 - Published in Atmos. Chem. Phys. Discuss.: 7 August 2015

Revised: 2 November 2015 - Accepted: 19 November 2015 - Published: 10 December 2015

\begin{abstract}
Visible Multifilter Rotating Shadowband Radiometer (vis-MFRSR) data were collected at Storm Peak Laboratory (SPL), a mountain-top facility in northwest Colorado, from 1999 to 2011 and in 2013. From 2011 to 2014, in situ measurements of aerosol light scattering were also obtained. Using these data sets together, the seasonal impact of dust and biomass burning is considered for the western USA. Analysis indicates that the median contributions to spring and summer aerosol optical depth (AOD) from dust and biomass-burning aerosols across the data set are comparable. The mean AOD is slightly greater in the summer, with significantly more frequent and short-duration high AOD measurements due to biomass-burning episodes than in the spring. The Ångström exponent showed a significant increase in the summer for both the in situ and vis-MFRSR data, suggesting an increase in combustion aerosols. Spring dust events are less distinguishable in the in situ data than the column measurement, suggesting that a significant amount of dust may be found above the elevation of SPL, $3220 \mathrm{~m}$ a.s.l.

Twenty-two known case studies of intercontinental dust, regional dust, and biomass-burning events were investigated. These events were found to follow a similar pattern, in both aerosol loading and Ångström exponent, as the seasonal mean signal in both the vis-MFRSR and ground-based nephelometer. This data set highlights the wide-scale implications of a warmer, drier climate on visibility in the western USA.
\end{abstract}

\section{Introduction}

The effect of aerosol particles is critical in understanding Earth's radiation budget, yet significant uncertainties in the radiative properties of aerosols globally and on regional scales prevent the needed accuracy within numerical models to define future climate change. When considering only the direct effect of aerosols on global climate, the Intergovernmental Panel on Climate Change (IPCC) uncertainty estimate is currently greater than the effect at $-0.35 \pm 0.5 \mathrm{Wm}^{-2}$ and in urgent need of further research (Boucher et al., 2013). As the radiative impact depends on aerosol composition and size, characterization of the aerosol population is necessary. Furthermore, understanding the source region of the aerosol is critical for emission control policy both for air quality and visibility. In 1977, the Clean Air Act amendments began regulating visibility in 156 Class I areas, which include many national wilderness areas and memorial parks (Watson, 2002). A majority of these areas are in the western USA. Most recently, The US Environmental Protection Agency (EPA) Regional Haze Rule (US EPA, 2003) mandated a schedule of increasing emission controls to achieve "natural visibility conditions" in these Class I areas by 2064 . Unlike the rest of the USA, visibility has not improved in the Intermountain/southwestern $(-116$ to $-100^{\circ}$ longitude) regions over the last 2 decades (Hand et al., 2014) and, in fact, some aerosol contributors to visibility degradation are increasing.

Tangible evidence for intercontinental transport of pollution associated with desert dust and smoke from biomass burning has changed air pollution from a local issue to one 
of global scope (Akimoto, 2003). Remote locations in the western USA are influenced both by domestic emissions and intercontinental transport of aerosols (e.g., Bodhaine, 1996; Yu et al., 2012). For example, an analysis by VanCuren and Cahill (2002) of the long-term data set provided by the Interagency Monitoring for Protected Visual Environments (IMPROVE) network indicated that Asian outflow including mineral dust is a frequent component of the lower free troposphere over much of North America, implying that Asian outflow to the USA is not solely limited to episodic springtime episodes. In a later study with three sites in California located at different elevations, VanCuren et al. (2005) demonstrated a distinct separation between the stable marine boundary layer and the troposphere. This layer separation resulted in isolation of free tropospheric air, allowing mountain sites $(>2 \mathrm{~km})$ to be consistently dominated by Asian continental aerosols. Kavouras et al. (2009) identified 610 days between 2001 and 2003 where dust was the major contributor to severe visibility reduction in an area of the western USA. Using a variety of techniques, they assigned dust origins to local, regional, or transboundary (Asian) sources on 496 of those days. In contrast to previous studies, dust sources were predominantly local (201 cases) and regional (240 cases). Asian sources were most significant on only 55 days, mainly during spring. Fischer et al. (2009) combined SeaWiFS aerosol optical thickness over the Taklamakan and Gobi Deserts with IMPROVE observations in the northwestern USA to study surface aerosol variability with regard to Asian dust emissions. Results indicated that a significant $(50 \%)$ amount of the interannual variability in springtime average $\mathrm{PM}_{2.5}$ and $\mathrm{PM}_{10}$ (particles smaller than 2.5 and $10 \mu \mathrm{m}$ in diameter, respectively) can be explained by Asian dust emissions. Overall, as shown by $\mathrm{Yu}$ et al. (2008), spring is the most active season for trans-Pacific transport of aerosols due to the active extratropical cyclones combined with strong midlatitude westerlies; however, this transport occurs throughout the year. More recently, by integrating satellite measurements $\mathrm{Yu}$ et al. (2012) found that interannual variations of aerosol optical depth (AOD) over the North Pacific basin are smaller for dust than combustion aerosols and likely attributable to Eurasian fires (i.e., especially large fires in 2003 and 2008). Consistent with the prior studies, the trans-Pacific dust dominates the imported aerosol mass $(88 \%)$ relative to combustion aerosol $(6 \%)$, and transport occurs predominately above the boundary layer, resulting in elevated dust layers at 2-6 km (Yu et al., 2012). Previously Asian dust was observed at Storm Peak Laboratory, a mountain-top laboratory in northern Colorado, associated with a high-pressure system and elevated levels of gaseous elemental mercury (Obrist et al., 2008).

Human activities such as livestock grazing have also increased dust in the western interior USA by disturbing natural, stable surfaces such as cryptobiotic soils and physical crusts in the extensive deserts (Belnap and Gillette, 1998; Reynolds et al., 2001). With sediment cores from two alpine lakes in the San Juan Mountains of southwestern Colorado, Neff et al. (2008) showed that dust accumulation rates over the last 150 years are more than 5 times greater than the average accumulation over the previous 5000 years. Based on ensemble back trajectories, geostationary remote sensing data, and the size of the dust particles extracted from snow (i.e., greater than $10 \mu \mathrm{m}$ ), the dust in these sediment cores appears to be predominantly from the western USA. The Upper Colorado River basin currently experiences 4 to 12 late winterand springtime dust deposition events each year (Neff et al., 2008; Painter et al., 2010). Using in situ data from Storm Peak Laboratory and ensemble back trajectories, Hallar et al. (2011a) presented evidence of aerosol incursions at the mountain site from multiple dust storms originating in the Four Corners region of the western USA during the spring of 2010.

Wildfires are also increasing in the western USA, as shown by a 6-fold increase in annual area burned from 1986 to 2003 in comparison to 1970-1986 (Westerling et al., 2006). Using data from 1984 to 2011, Dennison et al. (2014) demonstrated significant increasing trends in the number of large fires and/or total large fire area per year, coinciding with trends of increasing drought severity across the western USA. Augustine et al. (2008) observed increasing AOD in the Intermountain West (Fort Peck, Montana and Table Mountain, Colorado) from 1997 to 2007, and attributed this increase to an upsurge in wildfire activity. It is predicted that wildfires will increase summertime organic aerosol concentration by $40 \%$ by the 2050 s in the western USA (Spracklen et al., 2009).

Here, we systematically analyze the relative contributions of dust and biomass-burning aerosols from intercontinental, local, and regional sources (e.g., the Colorado Plateau) with observed aerosol loading at a high-altitude site. The analysis was performed using a long-term record of radiometer data (1999-2011 and 2013) coupled with a more recent record (2011-2014) of in situ aerosol optical properties located at a remote mountaintop location in the Rocky Mountains within the western USA.

\section{Methodology}

\subsection{Location}

Storm Peak Laboratory (SPL; 3220 ma.s.l.; $40.455^{\circ} \mathrm{N}$, $106.745^{\circ} \mathrm{W}$ ), operated by the Desert Research Institute, is located on the west summit of Mount Werner in the Park Range, $10 \mathrm{~km}$ from Steamboat Springs in northwestern Colorado. SPL is situated at tree line on a $70 \mathrm{~km}$ ridge oriented perpendicular to the prevailing westerly winds. SPL is $1120 \mathrm{~m}$ above the nearest population center (Steamboat Springs, CO; population $\sim 12000$ ). This site has been used in cloud and aerosol studies for more than 25 years (e.g., Lowenthal et al., 2002; Borys and Wetzel, 1997). The long- 
term measurements made at this remote location have allowed studies of the long-term trends in aerosol properties (e.g., Asmi et al., 2013). The site provides a unique opportunity to study the influence of dust transport on the local radiative forcing and to investigate the relative importance of dust and biomass burning on the seasonal aerosol loading.

\subsection{Instrumentation}

The visible Multifilter Rotating Shadowband Radiometer (vis-MFRSR) deployed at SPL was produced by Yankee Environmental Systems, Inc., and is part of the US Department of Agriculture (USDA) UV monitoring network (Bigelow et al., 1998). The shadow-band design allows the vis-MFRSR to measure the total and diffuse horizontal and direct normal solar irradiance. The vis-MFRSR, described in detail within Harrison et al. (1994), measures solar irradiance in spectral bands at nominal wavelengths of 415, 500, 615, 673, 870, and $940 \mathrm{~nm}$, with a full width at half maximum of $10 \mathrm{~nm}$. Each wavelength channel uses a silicon photodiode that has been hermetically isolated with an appropriate filter. The visMFRSR also possesses one unfiltered silicon diode that measures in the range of 300 to $1040 \mathrm{~nm}$. All photodiodes are illuminated by radiation passing through a Lambertian diffuser made of Spectralon that provides an approximate cosine response. The instrument is maintained at thermal equilibrium of $40^{\circ} \mathrm{C}$ and is environmentally sealed. The instrument performs measurements every $15 \mathrm{~s}$, which are integrated into 3 min averages and recorded by the computer/data logger for the vis-MFRSR. The vis-MFRSR data are uploaded nightly to an off-site server using an Internet connection. Daily averages of aerosol optical depth were calculated from measurements that passed our cloud screening. At least 24 min of clear skies were required for a daily average, but typical daily values included much more data than this minimum.

A TSI integrating nephelometer (model 3563, St. Paul, Minnesota) was initially deployed at SPL in January 2011 to measure aerosol light scattering $\left(\sigma_{\mathrm{sp}}\right)$. Here, the continuous, in situ aerosol light-scattering data obtained between January 2011 and June 2014 is used as a surrogate for aerosol loading at the surface. The nephelometer measures total $\left(7-170^{\circ}\right)$ and backward $\left(90-170^{\circ}\right)$ light scattering by aerosol particles at three wavelengths: blue $(450 \mathrm{~nm})$, green $(550 \mathrm{~nm})$, and red $(700 \mathrm{~nm})$ at the conditions (temperature, relative humidity, and pressure) inside the nephelometer (i.e., not ambient) (Anderson et al., 1996; Anderson and Ogren, 1998). The nephelometer operated at a volumetric flow rate of approximately $27 \mathrm{Lmin}^{-1}$. Data were collected with a $1 \mathrm{~Hz}$ sample rate and recorded as $1 \mathrm{~min}$ averages. Auxiliary equipment includes a 1 and $10 \mu \mathrm{m}$ impactors upstream of the nephelometer and absorption instruments. Here, only measurements downstream of the $10 \mu \mathrm{m}$ impactor are used. SPL is located in an environment with typically low dew-point temperatures, and a heater is not required for the nephelometer. Over the 3.5 years of nephelometric measurements at
SPL, the nephelometer sample RH exceeded $40 \%$ less than $0.1 \%$ of the time (29 hourly measurements out of 24235 total hours).

\section{Calibration and corrections}

\subsection{Vis-MFRSR}

The vis-MFRSR must be calibrated continuously to provide the necessary accuracy for measurements of optical depth. A derivation of the AOD requires an estimate of the visMFRSR voltage response at the top of the atmosphere. In the absence of clouds, the direct solar irradiance measured by the vis-MFRSR is determined by

$V(\lambda)=V_{o}(\lambda) \exp [-\tau(\lambda) m]$

where $V(\lambda)$ is the voltage induced by direct solar irradiance at a wavelength $\lambda$ measured by the vis-MFRSR, and $V_{o}(\lambda)$ is the equivalent voltage due to direct normal irradiance at the top of the atmosphere as a function of $\lambda . \tau$ is the total column optical depth due to scattering and absorption, and $m$ is the air mass traversed by the direct solar beam relative to the air mass in the zenith direction.

Following methods presented in Michalsky et al. (2001, 2010) the calibration of the vis-MFRSR wavelength channels is achieved using Langley plots. A Langley plot is a graph of the natural $\log$ of the direct solar irradiance vs. air mass within a narrow spectral interval. Langley plots for air masses between 2 and 6 , corresponding to measurements made between 60 and $80^{\circ}$ from the zenith, were screened for stable conditions and included morning and afternoon periods. The nearest 20 successful Langley results to any day in the visMFRSR data stream were then used to provide a calibrated voltage response at the top of the atmosphere $\left(V_{o}\right)$ for the vis-MFRSR wavelength channels for that date. These $20 V_{o} \mathrm{~s}$ at $500 \mathrm{~nm}$ are divided to the corresponding $V_{o} \mathrm{~s}$ at $870 \mathrm{~nm}$, and mean of the $V_{o} \mathrm{~s}$ in the interquartile range of these ratios (Michalsky et al., 2010) is used as the best estimate of the $V_{o} \mathrm{~s}$ for all wavelengths. This procedure eliminates false Langley plots in atmospheric conditions that could skew the estimation of $V_{o}$ (Kiedron and Michalsky, 2015). A final smoothing fit is applied to the stream of robust $V_{o}$ values for the times series using a loess filter, as described in Michalsky et al. (2010). Figure 1 illustrates the results of the calibration using Langley plots. The loess estimate is used in the final analysis of aerosol optical depth to address the longterm variation in the measured $V_{o}$ due to the degradation and temperature sensitivity of the vis-MFRSR sensor and to extrapolate to the value of $V_{o}$ for the beginning and end of a deployment of the vis-MFRSR. The $V_{o}$ s are normalized to unit solar distance for the above processing and then adjusted to the Earth-Sun distance for use on the day when aerosol optical depths are calculated using the calibrated $V_{o}$ s. 


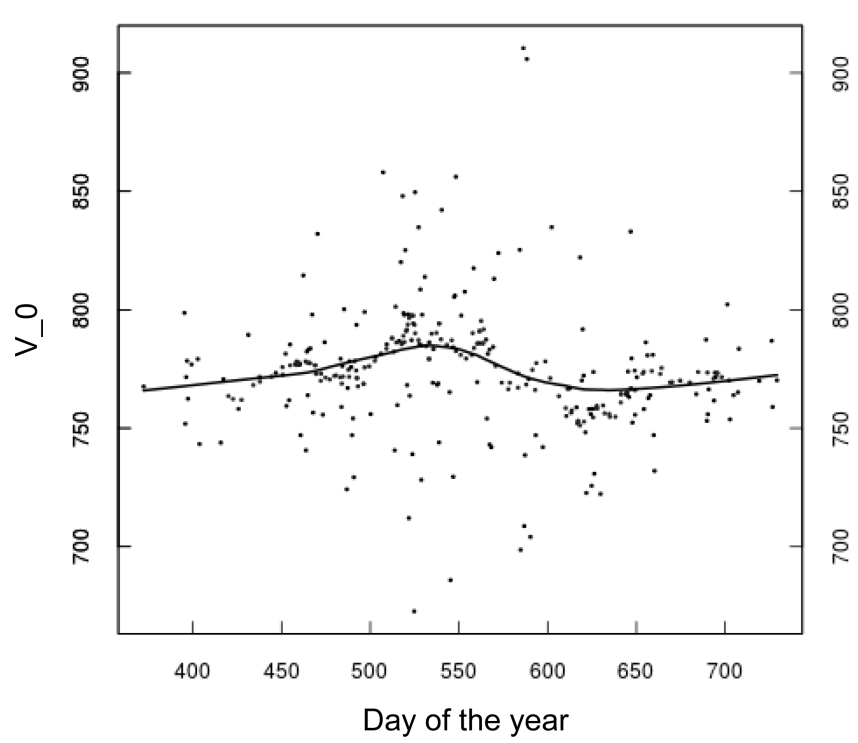

Figure 1. Calibration results for the $415 \mathrm{~nm}$ channel from visMFRSR Langley plots. All $V_{o}$ s from the Langley plots are shown with dots. The loess estimate (black curve) is used for the assigned $V_{o}$ in the aerosol optical depth analyses.

A comparison between an vis-MFRSR calibrated in this manner and calibration at Mauna Loa Observatory (Michalsky and LeBaron, 2013) has indicated that this technique is robust to within a percent. A calculation of the optical depth using the calibrated value for $V_{o}$ derived above should be accurate to an optical depth of 0.01 . Additional uncertainty could be expected from a changing cosine response of the Lambertian receiver. The cosine response of the Lambertian receiver from the vis-MFRSR instrument at SPL was measured in each of the seven channels in 1998, 2003, and 2012. The measured cosine response was used to reduce data until a new cosine response was measured. For example, the cosine response from 1998 was used until 2003, the 2003 response until 2012, and then the 2012 response for subsequent data reduction. The 1998 and 2003 cosine responses were remarkably similar. There was no final measurement of the cosine response when the detector assembly was rebuilt in 2012. This means that if the cosine response changed during the 9-year period between 2003 and 2012, we do not have a measurement of that change. However, given that the 1998 and 2003 cosine responses were quite similar, we assume that there was little change through 2012. The small change in cosine response between 1998 and 2003 suggests that SPL is a very clean site (little local contamination), which minimizes the Lambertian receiver degradation. The 2012 cosine response would not be expected to resemble the earlier cosine responses because the detector head was completely rebuilt.

\subsection{Cloud screening of vis-MFRSR data}

The primary mechanism used to cloud screen the AOD samples derived from the vis-MFRSR measurements is to examine the short-term stability of the AOD. The cloud screening of AOD data occurs in a two-step process, discarding those measurements whose variability indicates the strong possibility of passing clouds. An AOD measurement is cloud screened if the following conditions are met. In the first step a collection of eight contiguous data points, the change in optical depth between each AOD measurement cannot exceed 0.02 , and the change over the entire collection of measurements cannot exceed more than 0.03 (Michalsky et al., 2010). The second step scales these limits according to the estimated magnitude of the optical depth, e.g., lower limits for low optical depths. In total, 2420003 min measurements during 1999-2013 passed the screening methodology, resulting in 2252 daily-averaged, cloud-screened vis-MFRSR data points.

\subsection{Nephelometer}

The nephelometer was calibrated once per year with particlefree air and $\mathrm{CO}_{2}$. Zero checks on filtered air were performed hourly. The nephelometer data were corrected for truncation and illumination non-idealities, as suggested by Anderson and Ogren (1998). Overall, the uncertainty in scattering arising from nephelometer non-idealities is less than $10 \%$ for submicron particles (e.g., Anderson et al., 1996). For coarsemode particles (diameter greater than 1 micron), the nephelometer uncertainty increases for total scattering (20-50\%). This increase is due to the inability of the nephelometer to sense near-forward scattering, which is an increasingly dominant part of the total scattering for large particles (Anderson et al., 1996). Because we consider all aerosol particles less than 10 micron (not just coarse aerosol) and use hourlyaveraged data, the uncertainties will tend toward the lower side of the uncertainty range (Sheridan et al., 2002).

\section{4 Ångström exponent}

The Ångström exponent $(\alpha)$ is inversely dependent on the mean particle radius. It is a power-law relation of the observed AOD and scattering to the particular optical wavelength $\lambda$. As a non-dimensional measure of wavelength dependence, $\alpha$ can be calculated from both the vis-MFRSR AOD measurements $(\tau)$ and the nephelometer scattering measurements $\left(\sigma_{\mathrm{sp}}\right)$ :

$\alpha_{\mathrm{Neph}}=\ln \left(\sigma_{\mathrm{sp}, \lambda 1} / \sigma_{\mathrm{sp}, \lambda 2}\right) / \ln (\lambda 1 / \lambda 2)$,

$\alpha_{\text {vis-MFRSR }}=\ln \left(\tau_{\lambda 1} / \tau_{\lambda 2}\right) / \ln (\lambda 1 / \lambda 2)$,

where $\lambda 1$ and $\lambda 2$ represent the wavelengths used in the calculation for each instrument: vis-MFRSR $\lambda 1=500 \mathrm{~nm}$, $\lambda 2=870 \mathrm{~nm}$; nephelometer $\lambda 1=450 \mathrm{~nm}, \lambda 2=700 \mathrm{~nm}$. 
The Ångström exponent varies with size distribution and thus is frequently employed as a qualitative indicator of aerosol type. This parameter is well suited to differentiate between smoke and dust-related aerosol populations. Values of $\alpha$ can range from approximately 2 for submicrometer accumulation-mode particles, such as those produced during biomass burning, to near 0 for coarse-mode aerosols such as dust (e.g., Aryal et al., 2014; Clarke et al., 2007; Russell et al., 2010).

\subsection{Identification of dust and fire events at SPL}

In order to investigate seasonal differences in aerosol loading, specific known case studies of dust and biomass-burning aerosols reaching SPL were considered. These events were identified from the literature and available data sets, as described below, and highlighted in Table 1 .

\section{Dust events}

\subsection{Intercontinental}

Table 1 lists two intercontinental dust events observed at SPL and additional details on this pair of events are provided here. The first dust event resulted from a massive dust storm in Mongolia's Gobi desert in April of 2001, which lofted both mineral dust and biomass-burning aerosols. These aerosols were sampled during the Asian Pacific Regional Aerosol Characterization Experiment (ACE-Asia) field studies with aircraft, ships, satellites, and surface sites (Seinfeld et al., 2004). The dust was lofted ahead of a surface cold front within the warm conveyor belt of a midlatitude cyclone traveling across the Pacific and decaying as it flowed anticyclonically into an upper-level ridge. The dust was seen throughout the US atmospheric boundary layer, with almost no reduction in concentration (Jaffe et al., 2003; Kavouras et al., 2009; Gong et al., 2003). Simulations using a global transport model (GEOS-Chem) indicate that transpacific transport during this dust event was restricted to the lower free troposphere above the boundary layer, which facilitates contact with elevated terrain in the northwestern USA (Heald et al., 2006). This significant event was observed at SPL on 15-16 April 2001.

Asian dust was observed again at SPL from 27 April to 1 May 2006 via the vis-MFRSR. This dust storm was well characterized at Whistler Peak in British Columbia and via the NCAR C-130 aircraft flying relatively near to Whistler during the INTEX-B study (Leaitch et al., 2009). Dust was observed between 2 and $5.3 \mathrm{~km}$ at Whistler, BC, from 22 April to 15 May 2006. From the comprehensive INTEX$\mathrm{B}$ data set, which included a quadrupole aerosol mass spectrometer aboard the C-130 (Dunlea et al., 2009) with a highresolution time-of-flight aerosol mass spectrometer (Sun et al., 2009) and an offline ion chromatography on the ground, Leaitch et al. (2009) concluded that coarse particles of dust accumulated sulfate, nitrate, and organic material, which diminished the role of these compounds in indirect radiative forcing but potentially enhanced their roles in direct radiative forcing.

\subsection{Regional}

To systematically investigate regional dust events reaching SPL, data collected at the Senator Beck Basin Study Area, operated by the Center for Snow and Avalanche Studies (CSAS), 10 miles north of Silverton, Colorado, in the western San Juan Mountains, were examined. CSAS operates a multitude of instrumentation for hydrologic modeling validation, which is described in detail within Landry et al. (2014). Both upwelling and downwelling broadband pyranometers and a filtered near-infrared/shortwave-infrared pyranometers are used in combination. The difference in reflected radiation measured by these paired pyranometers enables the measurement of contaminants such as dust in the snow surface (Painter et al., 2007, 2012; Skiles et al., 2012). These "dust on snow" events are cataloged with wind speed and wind direction, starting in May 2006, and available at http://www.codos.org/. Using this catalog, potential SPL dust events were identified when the wind direction was heading towards SPL (northwestern quadrant between 180 and $270^{\circ}$ ). Based on HYSPLIT ensemble back trajectories (Draxler and Rolph, 2015) and the measured wind speed at CSAS, it took approximately $24-48 \mathrm{~h}$ for the dust to reach SPL from CSAS.

For earlier years (2007-2008), the annual CSAS reports were used to select only the largest dust event each year observed at Senator Beck Basin, and it was estimated that the dust reached SPL in $24 \mathrm{~h}$ (Hallar et al., 2011a). From 2009 to 2010, aerosol particle sizer data were used to identify the initial start and end time of each event at SPL within the initial window suggested by the CSAS data as described in Hallar et al. (2011a). The mean dust particle size by number during the 2009-2010 dust events was approximately $1 \mu \mathrm{m}$. For events between 2011 and 2013, the nephelometer data were used to identify the initial start and end time of the event at SPL. All regional dust case studies identified in this manner are listed in Table 1.

\subsection{Fires}

The impact of the wildfires on aerosol loading and air quality over Colorado was analyzed by Val Martin et al. (2013) using AOD measured by the MODerate resolution Imaging Spectroradiometer (MODIS) aboard the Terra satellite in combination with surface $\mathrm{PM}_{2.5}$ (particles smaller than $2.5 \mu \mathrm{m}$ in diameter) averaged over 10 sites within the Colorado Front Range corridor. They classified nine main fire events that were identified between 2000 and 2012. During this study these events were investigated further, and those with available data from SPL are listed within Table 1. For example, from 3 to 7 June 2011, Storm Peak Laboratory was 
Table 1. Dust and biomass-burning events observed at SPL.

\begin{tabular}{|c|c|c|c|c|}
\hline $\begin{array}{l}\text { Start time } \\
\text { (UTC) }\end{array}$ & $\begin{array}{l}\text { End time } \\
\text { (UTC) }\end{array}$ & & $\begin{array}{c}\text { Vis-MFRSR data } \\
\text { available }\end{array}$ & $\begin{array}{c}\text { Nephelometer data } \\
\text { available }^{\text {b }}\end{array}$ \\
\hline \multicolumn{5}{|l|}{ DUST EVENT } \\
\hline 15 April 2001, 12:00 & 16 April 2001, 12:00 & Asian & $\mathrm{X}$ & \\
\hline 27 April 2006 & 1 May 2006 & Asian & $X$ & \\
\hline Regional events & & WindDir. at CSAS & & \\
\hline 19 April 2007, 19:00 & 20 April 2007, 07:00 & 201 & $\mathrm{X}$ & \\
\hline 16 April 2008, 19:00 & 17 April 2008, 07:00 & 219 & $\mathrm{X}$ & \\
\hline 4 April 2009, 05:00 & 5 April 2009, 07:00 & 206 & $\mathrm{X}$ & \\
\hline 13 April 2010, 08:00 & 13 April 2010, 13:00 & 188 & $\mathrm{X}$ & \\
\hline 22 May 2010, 09:00 & 24 May 2010, 15:00 & 192 & $X$ & \\
\hline 22 April 2011, 22:00 & 24 April 2011, 00:00 & 258 & & $\mathrm{X}$ \\
\hline 1 May 2011, 12:00 & 4 May 2011, 06:00 & 279 & & $\mathrm{X}$ \\
\hline 5 May 2011, 09:00 & 11 May 2011, 06:00 & 206 & $X$ & $X$ \\
\hline 27 May $2011,18: 00$ & 29 May $2011,12: 00$ & 243 & & $\mathrm{X}$ \\
\hline 7 March 2012, 09:00 & 8 March 2012, 09:00 & 197 & & $X$ \\
\hline 20 March 2012, 09:00 & 22 March 2012, 00:00 & 193 & & $\mathrm{X}$ \\
\hline 27 March 2012, 18:00 & 29 March 2012, 12:00 & 207 & & $\mathrm{X}$ \\
\hline 2 April 2012, 20:00 & 3 April 2012, 10:00 & 198 & & $\mathrm{X}$ \\
\hline 7 April 2012, 18:00 & 11 April 2012, 14:00 & 201 & & $\mathrm{X}$ \\
\hline 20 May 2012, 00:00 & 23 May $2012,14: 00$ & 213 & & $X$ \\
\hline 24 May 2012, 14:00 & 1 June 2012, 00:00 & $217^{\mathrm{a}}$ & & $\mathrm{X}$ \\
\hline 16 April 2013, 20:00 & 20 April 2013, 02:00 & 206 & & $\mathrm{X}$ \\
\hline 25 May 2013, 00:00 & 25 May $2013,18: 00$ & 207 & & $X$ \\
\hline FIRE EVENT & & Origin & & \\
\hline 27 July 2000 & 6 August 2000 & NW USA 1 & $\mathrm{X}$ & \\
\hline 15 June 2002 & 10 July 2002 & Hayman & $\mathrm{X}$ & \\
\hline 30 July 2002 & 3 August 2002 & $\mathrm{AR}, \mathrm{OR}, \mathrm{CA}$ & $X$ & \\
\hline 4 September 2006 & 9 September 2006 & $\mathrm{CA}$ & $X$ & \\
\hline 29 August 2009 & 3 September 2009 & Station Fire & $\mathrm{X}$ & \\
\hline 4 June 2011, 07:00 & 8 June 2011, 00:00 & Wallow & $\mathrm{X}$ & $\mathrm{X}$ \\
\hline 30 June 2012, 07:00 & 5 July 2012, 07:00 & Waldo/High Park & & $X$ \\
\hline 10 August 2012, 07:00 & 18 August 2012, 07:00 & NW USA 2 & & $X$ \\
\hline 21 September 2012, 07:00 & 23 September 2012, 07:00 & NW USA 3 & $\mathrm{X}$ & $X$ \\
\hline
\end{tabular}

${ }^{a}$ Average of three consecutive dust events at CSAS. ${ }^{b}$ Aerosol optical properties for events sampled by nephelometer are provided in the Supplement.

strongly impacted by outflow from the Wallow fire in Arizona. The Wallow fire is Arizona's largest recorded wildfire to date (215000 ha) (Kennedy and Johnson, 2014). Smoke transported from this fire was observed by many instruments at SPL. During the peak of the fire on 6 June from 06:00 to 23:00 MST, a distinct particle size mode was observed at $250 \mathrm{~nm}$ (a typical mode at SPL is below $100 \mathrm{~nm}$ ), while nephelometer scattering (at $550 \mathrm{~nm}$ ) increased from typical June values of $\sim 15 \mathrm{Mm}^{-1}$ to greater than $100 \mathrm{Mm}^{-1}$ and the visMFRSR AOD500 values were above 0.2 during the smoke incursion.

\section{Results}

The long-term time series of vis-MFRSR cloud-screened and calibrated AOD at $500 \mathrm{~nm}$ is shown in Fig. 2. Figure 2 and all vis-MFRSR analysis presented here use the dailyaveraged data. Figure 2 shows multiple statistical fits to the vis-MFRSR data. The least square fit (blue dashed line) is higher than the loess fit (green line) because it is sensitive to outlier AOD values. Figure 2 indicates strong interannual variability but also a consistent seasonal cycle with lowest AOD values observed in the winter months. There is, however, neither a strong long-term trend seen in the AOD data nor a statistically significant increase in AOD in the midafternoon (not shown). The lack of a daily AOD cycle supports the conclusion that the majority of the aerosol popula- 


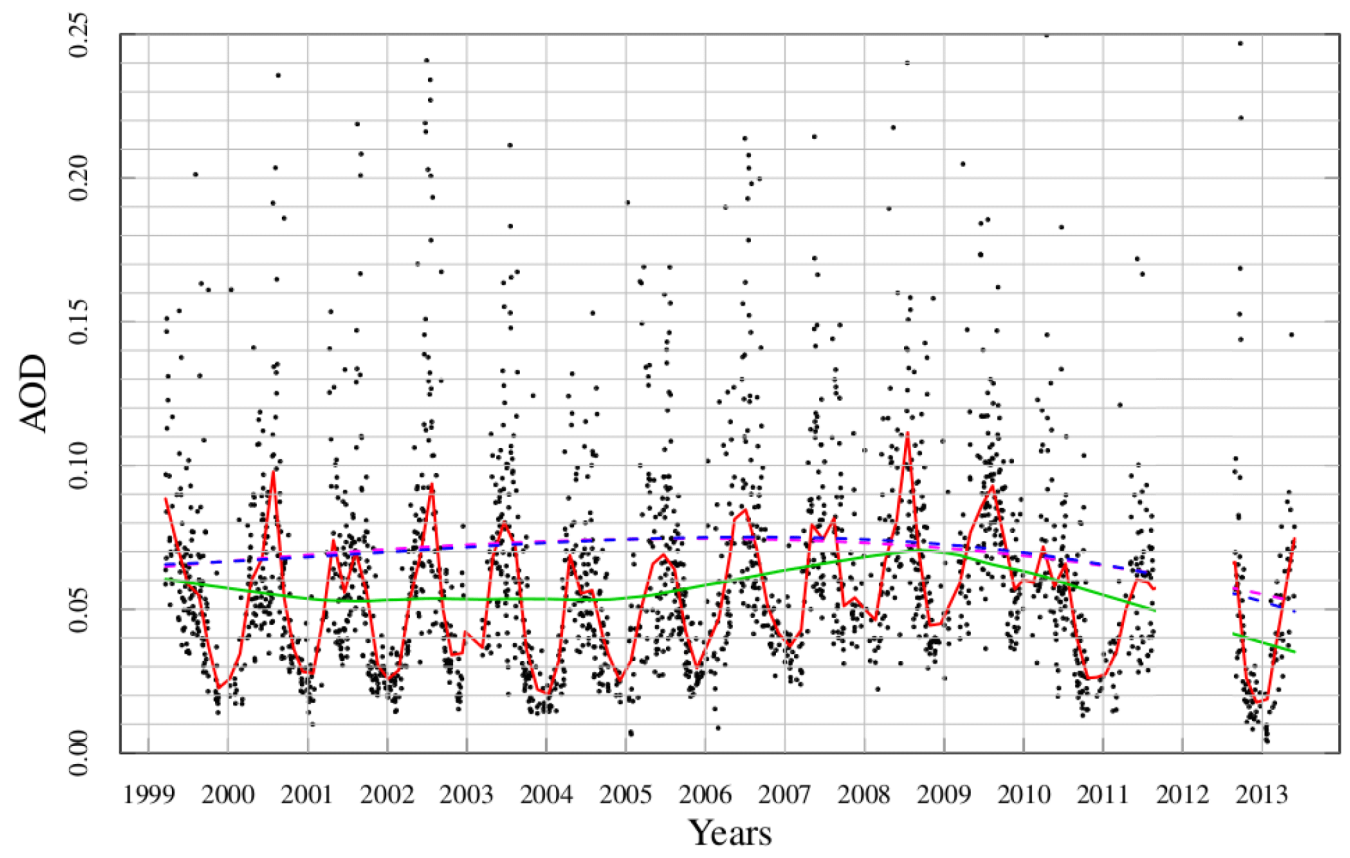

Figure 2. Black dots are 2252 daily averages of AOD at $500 \mathrm{~nm}$. The red line is a loess fit with a 3-month window. The green line is a loess fit with a 5-year window. The blue dashed line is a least squares fit to a cubic polynomial. A year gap in the vis-MFRSR measurements occurred in 2011-2012. This interruption in vis-MFRSR operation was due to structural renovations at the SPL facility.

tion observed by the vis-MFRSR at SPL is not influenced by the boundary layer via mountain wave dynamics or regional new particle formation events (Hallar et al., 2011b). Newly formed particles dominate the number concentration in general at SPL but are too small to be optically active.

The top panels of Fig. 3 highlight the annual patterns in both the AOD and $\alpha_{\text {MFRSR }}$. The AOD demonstrates an increased aerosol loading in the spring (approximately 1 March-15 May; day of year (DOY) 61-136), with a slight decrease in early summer starting 1 June (DOY 160) and then a sustained stronger increase from mid-June until midAugust (DOY 170-225). The average and the standard deviation of the AOD for the spring is $0.069 \pm 0.0002$ (median $=0.061$ ) and for the summer is $0.099 \pm 0.0004$ (median $=0.074)$. As indicated by the low standard deviation the year-to-year season average variation in AOD is very small. Due to the episodic nature of biomass-burning events during the peak summer season, the summertime AOD has significantly more variability. The difference between the median spring and summer AOD, over this 13-year record, is small $(<0.01)$. In contrast to the relatively small difference in AOD in the spring and summer, there is a significant difference in the Ångström exponent between those two seasons. The average Ångström exponent during the spring is $0.912 \pm 0.0024$ (median $=0.865)$, while during the peak summer season the Ångström exponent is $1.64 \pm 0.01$ (median $=1.65$ ). From 1 April to 15 May (DOY 91-136), the Ångström exponent shows a more significant decrease, with an average value of
$0.876 \pm 0.0028($ median $=0.832)$, this period is denoted in Fig. 3 with vertical dashed lines.

This pattern suggests a difference in the aerosol size between the spring and summer observed at Storm Peak Laboratory. Specifically, there is an increase in coarse-mode aerosol loading during the spring, with the strongest signal in April and early May (DOY 91-136) when the lowest Ångström exponent values occur. This finding is consistent with the previous work, pointing to springtime transport of dust, both from local and remote sources to this region (e.g., Yu et al., 2012; Hallar et al., 2011a). Using nephelometer scattering data from approximately 1000 vertical profiles during numerous aircraft campaigns, Clarke and Kapustin (2010) calculated $\alpha_{\mathrm{Neph}}$ from scattering at 450 and $700 \mathrm{~nm}$ and then used $\alpha_{\mathrm{Neph}}>1.3$ to separate air masses consisting of smaller particles characteristic of combustion sources from air masses consisting of larger dust particles. At SPL, the summer aerosol appears to be dominated by smaller particles. Given the remote nature of SPL, these smaller aerosol particles are most likely combustion aerosol from biomass burning.

The vis-MFRSR and nephelometer instruments cover different time periods, and the plots (top and bottom panels of Fig. 3) show different (though related) aerosol parameters; therefore they should not be expected to be identical. Additionally, the nephelometer is an in situ measurement made at low RH whereas the vis-MFRSR is an integration of the ambient aerosol in the vertical atmospheric column. Nonetheless, they present a somewhat consistent picture of the sea- 

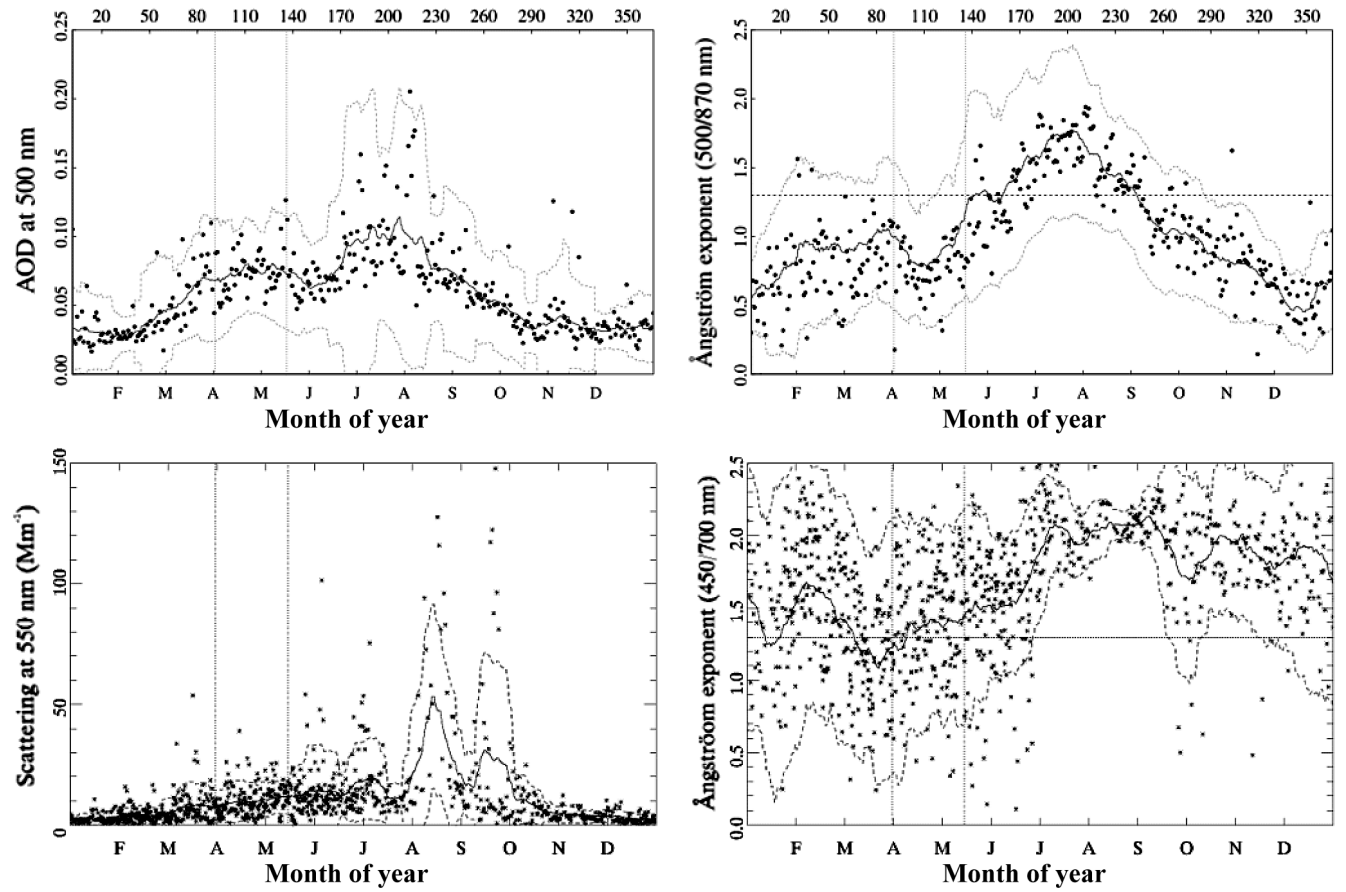

Figure 3. Left top panel shows seasonal pattern in AOD at $500 \mathrm{~nm}$ using data from 1999 to 2011 and 2013. Right top panel presents seasonal pattern in Ångström exponent $(500 \mathrm{~nm} / 870 \mathrm{~nm})$ for the same time range. Bottom panel shows seasonal pattern in nephelometer scattering and Ångström exponent. In all plots, the black dots are daily averages of the data. The dark gray line is a running average, calculated hourly using the data spanning 10 days before and after each position. The light gray lines indicate the standard deviation vertically from the running average. Vertical gray dashed lines denote the peak dust period, approximately 1 April-15 May (DOY 91-136). The Ångström exponent of 1.3 is highlighted with a dashed vertical line for instruments.

sonal cycle of loading and particle size. Similar to the visMFRSR, the nephelometer measurements show that there is a strong summer peak in aerosol loading due to biomassburning events. However, the nephelometer does not show the increase in loading in the spring that is seen by visMFRSR AOD and attributed to dust.

The nephelometer-derived Ångström exponent is higher in the summer than in other times of year (note: this figure shows only one summer of nephelometer measurements (2012) due both to construction downtime and instrument issues). As with the vis-MFRSR, the lowest nephelometer Ångström exponent values occur in the spring, but the dip in Ångström exponent values derived from the nephelometer occurs about a month earlier in the seasonal cycle (1 March-15 April; DOY 60-105) than is observed for the vis-MFRSR-derived Ångström exponent.

\section{Investigating seasonal patterns in relation to known case studies}

Using the case studies outlined above, specific events of dust and biomass-burning aerosols observed at SPL will be considered in relation to seasonal patterns. A scatter plot showing AOD vs. Ångström exponent is a common tool to clas- sify aerosol types, as it can provide information on aerosol loading and size (type) simultaneously (e.g., Toledano et al., 2007). Figure 4 presents the relationship between Ångström exponent and aerosol loading for the vis-MFRSR and nephelometer, respectively. Figure 4 identifies the data by spring and summer seasons using small colored symbols (green and red, respectively) and highlights events listed in Table 1 using large colored symbols as indicated in the legend.

For both instruments, different seasonal relationships exist between aerosol loading and the Ångström exponent, indicating that the aerosol load at SPL contains two seasonally distinct aerosol populations. The Ångström exponent increases with increasing AOD during the summer, and the Ångström exponent decreases with increasing AOD during the spring. Thus, the aerosol population contains larger particles, consistent with dust, in the spring, and smaller particles are observed in the summer months, which is consistent with biomass burning. This relationship between particle size and source is further established by highlighting the case studies in Table 1 by using larger symbols in Fig. 4.

For example, a 2001 dust storm originating in Mongolia (e.g., Seinfeld et al., 2004) was measured at SPL and is denoted in Fig. 4a as "2001 Asian Dust". At SPL, the dust was measured with several instruments including the aerodynamic particle sizer (TSI, Inc.), with an aerosol mode at 

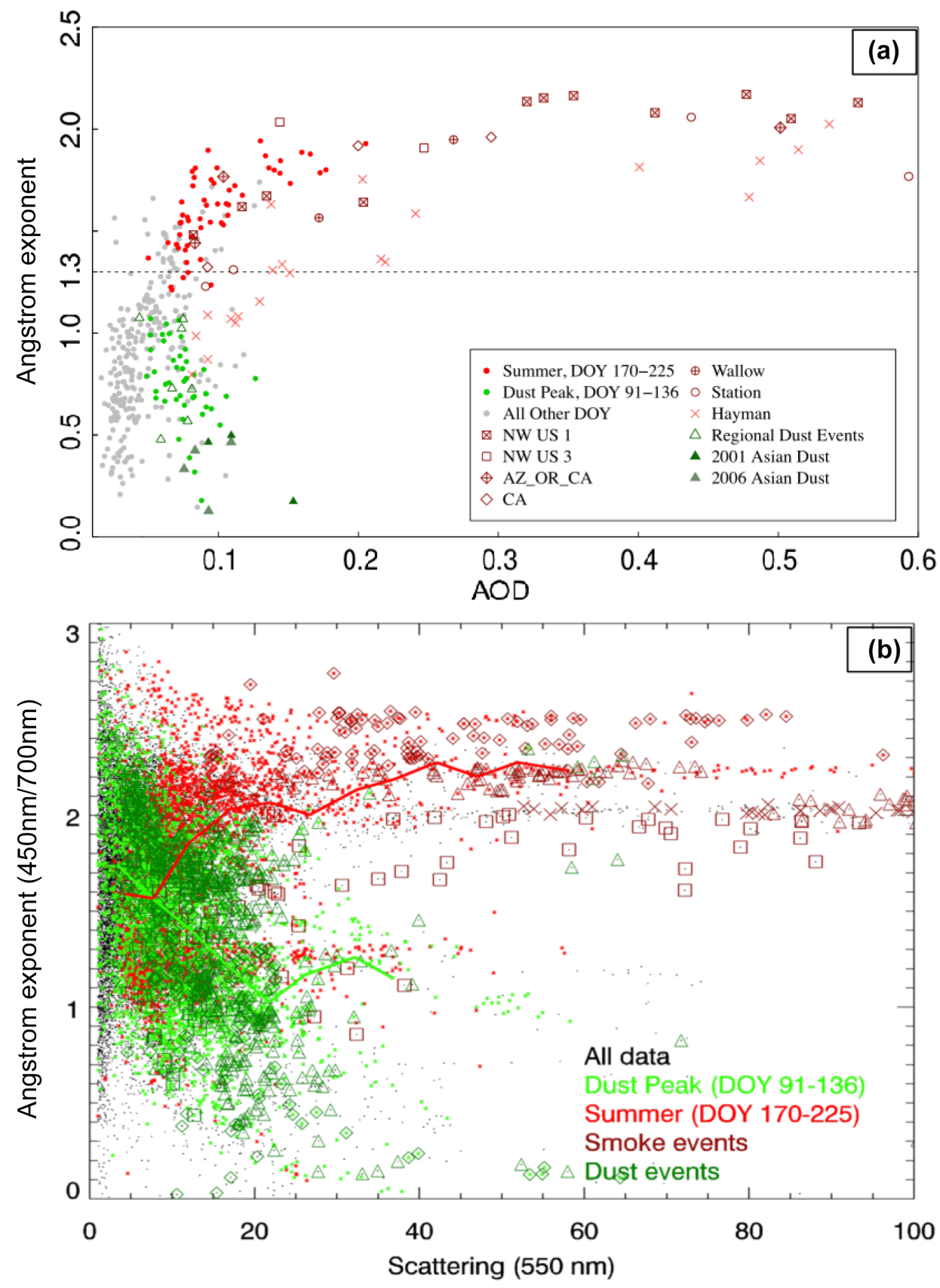

Figure 4. (a) AOD vs. Ångström measurements for vis-MFRSR. The dots represent daily-averaged measurements for the entire 1999-2011 and 2013 period of observation. The red indicates all measurements made from DOY 170 to 225 during peak summer season. Green indicates all measurements made during DOY 91-136, spring dust peak. The gray points indicate all measurements that were not made during these spring and summer periods. Events listed in Table 1 are shown with larger symbols; dust events are dark green, and fire events are maroon. (b) Relationship between hourly averaged Ångström exponent and scattering from the 2011-2013 nephelometer measurements. The lines represent the median value of Ångström and scattering for each scattering bin for either the dust peak or summertime range. The scattering bin limits are: $[1,5,10,15,20, \ldots, 95,100]$ and at least 15 valid data points are required in each scattering bin to generate a line segment. Regional dust events from Table 1 are shown in dark green; smoke events from Table 1 are shown in maroon. For the dust events, diamonds represent data from 2011, triangles 2012, and squares 2013. For the smoke events, the Wallow fire is indicated by squares, the Front Range fire is indicated by diamonds, the NW1 fire is indicated by triangles, and the NW2 fire is indicated by xymbols. 
$2 \mu \mathrm{m}$. The 2001 Asian dust event is notable in that it is well defined in the vis-MFRSR measurements for that year relative to other sources of AOD. During the event, the Ångström exponent decreased to 0.17 at SPL on 15 April, highlighting the large particle size. This finding is consistent with other measurements of this event at western, mid-western, and eastern US sun photometer stations, showing similar low Ångström exponents during this week (Thulasiraman et al., 2002). The 2006 Asian dust event ("2006 Asian Dust" in Fig. 4a) shows a similar relationship between Ångström exponent and AOD as was observed for the 2001 event. Ensemble HYSPLIT back trajectories (Draxler and Rolph, 2015) indicate that the air was transported directly from British Columbia, where prior dust measurements were conducted (Leaitch et al., 2009) to SPL. In comparison, the DOY 91136 (peak spring season) average Ångström exponent for 2004 is $1.09 \pm 0.005$, and the average AOD is $0.075 \pm 0.069$. The spring average Ångström for 2006 is $0.56 \pm 0.010$ with an average AOD of $0.07 \pm 0.001$. Although these 2 years have similar aerosol loading, as represented by the optical depths, the size of the aerosol and thus likely the composition is significantly different. As documented in the literature, severe Asian dust storms impacted Beijing and Korea, eventually reaching North America in April and May of 2006 (e.g., Papayannis et al., 2007; Lee and Cho, 2007; Leaitch et al., 2009). These average AOD and $\alpha_{\text {MFRSR values for the }}$ known Asian dust event are quite similar to many springtime daily average values in the long-term vis-MFRSR climatology at SPL, as shown in Fig. 4a. While not an absolute indication, they suggest that Asian dust is an important factor in the spring aerosol coarse-mode composition and total AOD at SPL. Significant Asian dust storms were not observed during the time frame when nephelometer data are available.

The regional dust events plotted in Fig. 4 (large green symbols) are consistent with typical springtime measurements (small green dots) of the Angström exponent and aerosol loading. All regional dust events measured by the vis-MFRSR have an Ångström exponent less than 1.3, as shown with the green triangle markers in Fig. 4a. This result is in agreement with Clarke and Kapustin (2010), which used $\alpha>1.3$ to separate air masses consisting of smaller particles characteristic of combustion sources from air masses consisting of larger dust particles. Surprisingly, the Asian dust storms observed at SPL have a smaller $\alpha_{\text {MFRSR }}$ than the regional dust storms. This is in contrast to the expectation that suggest an increasing $\mathrm{PM}_{2.5}$ to $\mathrm{PM}_{10}$ ratio with increasing dust plume age (e.g., Tong et al., 2012). As mentioned previously, regional dust events observed at SPL between 2009 and 2011 had a mean dust particle size by number of approximately $1 \mu \mathrm{m}$. As reported by Lee and Cho (2007) and Leaitch et al. (2009), Asian dust may have larger than $1 \mu \mathrm{m}$ mean diameter. These finding are consistent with the smaller $\alpha_{\text {MFRSR }}$ observed during Asian dust events in comparison to the regional dust storms found in this study. The nephelometer data for regional dust events indicate a wider range of Ångström exponents than was observed with the vis-MFRSR.

Finally, using the wildfires impacting Colorado, as identified by Val Martin et al. (2013), the impact of smoke on SPL was considered. Seven of the events were seen by the vis-MFRSR as listed in Table 1 and shown in Fig. 4 with red symbols. These events produced high AOD, reaching greater than 0.4 for several events, including the Haymaker and Station fires. Similar to the summertime daily averages observed by the vis-MFRSR, the Ångström exponent trends upward with increasing aerosol loading, for all fire events. Four of the wildfires were observed by the nephelometer, as listed in Table 1 and shown in Fig. 4b. In general, these events followed a pattern similar to the vis-MFRSR. Strong aerosol loading was observed during each of the fire events, with aerosol scattering above $80 \mathrm{Mm}^{-1}$. Table S1 provides statistics for fire and dust events, as measured by the nephelometer and filter-based absorption instrument of various aerosol optical properties (see Supplement for details). The scattering, absorption, Ångström exponent $\left(\alpha_{\mathrm{Neph}}\right)$, backscatter fraction (backscattering/total scattering), and single-scattering albedo at $550 \mathrm{~nm}$ are listed for each case study in Table S1. In general, dust events tend to have lower loading (both for scattering and absorption) than fire events; dust events tend to have lower Ångström exponent than fire events, indicating larger particles. There was no significant difference between dust events and fire events for backscatter fraction or singlescattering albedo.

\section{Discussion}

Several prior studies have used IMPROVE aerosol composition data to investigate the seasonality of dust events in the western USA (Kavouras et al., 2009; VanCuren and Cahill, 2002; Wells et al., 2007; Tong et al., 2012; Creamean et al., 2014). These studies provide evidence that Asian dust can be found in the western USA during all seasons (VanCuren and Cahill, 2002) with peak concentrations at the surface typically occurring in the spring (VanCuren and Cahill, 2002; Kavouras et al., 2009; Creamean et al., 2014). Dust generated from regional sources can also be found during all seasons, highlighting the impact of windblown dust across the year (Tong et al., 2012), although peak concentrations of regional dust at the surface typically occurred in the summer (Kavouras et al., 2009; Wells et al., 2007). Using IMPROVE data combined with MODIS imagery, Tong et al. (2012) found that regional dust in the western USA peaked from March to July. In contrast, the long-term vis-MFRSR observational data acquired at SPL do not indicate an appreciable amount of dust (Asian or regional) in the column above SPL outside of the spring season. It is important to acknowledge that this conclusion is based on the assumption that dust events sampled at SPL have distinctly different size distributions from other aerosol types and can be identified by the 
observation of low Ångström exponent values. Additionally in contrast to the previous studies, this study requires a dust concentration large enough to dominate the aerosol optical properties rather than relying on chemical detection methods.

It is difficult to differentiate local dust from intercontinental dust, outside of known case studies, using only optical measurements such as the vis-MFRSR and nephelometer because the timing (spring) and observations (AOD and

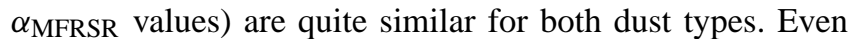
with chemical composition there is significant overlap between paired elemental ratio distributions for dust originating from the southwestern American desert and Asia (VanCuren and Cahill, 2002). In general the springtime daily average values in the long-term vis-MFRSR climatology at SPL suggest that dust (regional and Asian) may be an important factor in the spring aerosol coarse-mode composition and total AOD. Previous work by Augustine et al. (2008) attributed the secondary springtime maximum in AOD (and decrease in Angstrom exponent) observed at three western US surface radiation (SURFRAD) budget network sites to Asian dust transport. This work suggests that at SPL the springtime signal should be attributed to both regional and Asian dust.

By combining the vis-MFRSR and nephelometer data sets, we can begin to infer information pertaining to the vertical distribution of the aerosol. It is important to acknowledge that the nephelometer and vis-MFRSR measurements at SPL cover different time ranges and events, so we are relying on the climatological values obtained from these instruments to represent typical conditions of the column and at the surface ( $3220 \mathrm{~m}$ a.s.l.). The strong springtime increase in AOD in the vis-MFRSR is not observed in the in situ nephelometer light-scattering data. Additionally, the springtime decrease in Angström exponent is more pronounced in the vis-MFRSR data, compared to the in situ surface data. Thus, dust events are less distinguishable in the in situ data than the column measurement, suggesting that a significant amount of dust may be found above the elevation of SPL. This conclusion is further supported by the relatively invariant AOD signal across the day, suggesting that the majority of the aerosol population observed by the vis-MFRSR at SPL is not influenced by the boundary layer via mountain wave dynamics (i.e., diurnal upslope and downslope flow).

These results are supported by previous in situ, modeling, and remote sensing studies suggesting a more pronounced dust layer at higher elevations. Initially, with three sites in California located at different elevations (Trinidad Head, Trinity Alps, and Mount Lassen), VanCuren et al. (2005) demonstrated a distinct separation in aerosol chemistry between the stable marine boundary layer and the troposphere during the spring of 2002. Using eight-stage rotating drum impactors analyzed in 3-hour time steps by x-ray fluorescence, VanCuren et al. (2005) categorized Asian dust by using a $\mathrm{Fe} / \mathrm{Ca}$ ratio. Continuous Asian aerosol transport was found above the boundary layer, and Mount Lassen
(1755 m a.s.1.) was dominated by Asian continental aerosols, especially under conditions of strong synoptic forcing in the spring. Creamean et al. (2014) expanded upon VanCuren et al. (2005), using 10 years of IMPROVE data from 25 sites along the US West Coast, including 15 mountain sites. They found the highest concentration of Asian dust at the high elevations, due to the increased exposure to the free troposphere in comparison to the coastal sites, and peak concentrations in the spring at all sites. Wells et al. (2007) also saw a spring increase in dust concentration at high elevations attributed to intercontinental transport. Specifically, IMPROVE measurements and simulations from the Navy Aerosol Analysis and Prediction System of $\mathrm{PM}_{10}$ soil showed a 2-fold increase at a high-altitude site (Sawtooth National Forest, Idaho; $1980 \mathrm{~m}$ a.s.l.) compared to a low-altitude site (Kalmiopsis, Oregon; $90 \mathrm{~m}$ a.s.l.) in the spring from 2001 to 2004. In May 2007, measurements from the CloudAerosol Lidar with Orthogonal Polarization (CALIOP) observed dust clouds generated during a storm in China's Taklamakan Desert lofted to the upper troposphere $(8-10 \mathrm{~km})$ and transported more than one full circuit around the globe (Uno et al., 2009). Similar to the dynamic processes described by VanCuren et al. (2005), subsidence of a large-scale highpressure system caused the dust layer to descend into the lower troposphere (Uno et al., 2009). Yu et al. (2010) reported that CALIOP also observed dust layers between 4 and $6 \mathrm{~km}$ across the northwestern Pacific (from 0 to $50^{\circ} \mathrm{N}$ and from 50 to $140^{\circ} \mathrm{E}$ ) during the spring of 2007 ; this study was followed by work by Huang et al. (2015) demonstrating similar results for each April from 2007 to 2012. Again these prior studies are consistent with the conclusion that a significant amount of dust may be found above the elevation of SPL in the spring.

While dust (local and/or Asian) has a large seasonal impact on aerosol loading at SPL, our results also indicate that smoke may have a similar impact based on similar median AOD values for a dust-dominated spring (0.06) and a smokedominated summer (0.07). The SPL data set highlights the potential wide-scale implications of a warmer, drier climate on aerosol loading in the western USA. Increased drought in the western USA will result in increased wildfire activity and dust events. Dennison et al. (2014) demonstrated increasing trends in the number of large fires, most significant for mountain ecosystems, coinciding with increasing drought severity. The impact of drought is clearly evident within this data set. For example, in 2002, record or near-record precipitation deficits were observed throughout the western USA (Cook et al., 2004), creating conditions conducive to the very large Hayman fire (Schoennagel et al., 2004) in Colorado. The Hayman fire had a significant impact on the AOD at SPL, nearly $250 \mathrm{~km}$ north of the fire, resulting in the anomalously high summer AOD shown Fig. 2, along with the direct impact of the fire denoted in Fig. 4.

Depending upon its severity, increased aerosol loading in the western USA has many implications including effects on 
visibility, air quality, and climate feedbacks. Collaud Coen et al. (2013) studied long-term (> 10 years) trends in aerosol scattering from 24 observatories across the globe. The Mount Zirkel Wilderness IMPROVE site, a few kilometers away from SPL, was an anomaly compared to most of the stations studied, because it showed an increasing trend for aerosol scattering coefficient $\left(+4 \%\right.$ decade $\left.^{-1}\right)$. Mount Zirkel represents the only high-altitude IMPROVE site $(>2.5 \mathrm{~km})$ in the US Intermountain West with a long-term aerosol scattering record. Also using IMPROVE network data from 1990 to 2004, Murphy et al. (2011) found that in contrast to other seasons, elemental carbon increased in the summer within the Intermountain West due to an increase in summer wildfires. Hand et al. (2011) found an increase in fine soil concentrations in the Intermountain West from 1989 to 2008 via the IMPROVE data set, and this increase was most prominent in the springtime. The Intermountain West will continue to face significant difficulties maintaining mandated visibility faced with a drier climate, as there is a broad consensus among climate models that the Intermountain West will become more arid in the 21st century (e.g., Seager et al., 2007). Changes in aerosol loading, from increased wildfires and dust events, will have a direct impact on visibility, climate, and air quality (Val Martin et al., 2015). The results presented here suggest that biomass burning in the summer and spring time dust has had a significant impact on the Intermountain West over the last decade; however, emissions of these "natural" aerosols cannot be controlled in the same way that emissions from anthropogenic sources can be.

\section{Conclusions}

In the remote western USA, the role of seasonal dust and smoke in the aerosol population is an important issue for climate predictions and preserving visibility in pristine locations. Using the long-term vis-MFRSR and in situ aerosol optical data, the composition of spring and summer aerosol at SPL was investigated. The data clearly show a strong differentiation in the seasonal contribution of different aerosol types. In general, the spring AOD is dominated by coarsemode aerosols indicating dust, while the AOD in summer is dominated by aerosols in the fine mode likely associated with biomass burning. Differences between surface nephelometer measurements and column vis-MFRSR observations supports previous findings that springtime dust transport is found in elevated layers. Long-term analysis of the SPL AOD indicates that the median contribution of dust aerosol to spring and smoke aerosol to summer AOD over the course of 19992013 is comparable. These results suggest that both smoke and dust negatively impact scenic vistas in the Intermountain West and this impact may increase in a warmer, drier climate.

The Supplement related to this article is available online at doi:10.5194/acp-15-13665-2015-supplement.
Acknowledgements. Melanie Wetzel initiated the purchase and installation of the vis-MFRSR at Storm Peak Laboratory, and her efforts are greatly appreciated in creating this valuable data set. Ty Atkins provided technical assistance with the maintenance and data quality control for the aerosol optical instruments at SPL, and we are grateful. We appreciate initial analysis of the vis-MFRSR data by Tom Swissler. Chris Landry contribution of data from the Center for Snow and Avalanche Studies was critical to this effort. We appreciate the capabilities of the USDA UV-B Monitoring and Research Program for data storage and advice. The Steamboat Ski Resort provided logistical support and in-kind donations. The Desert Research Institute is a permittee of the Medicine-Bow Routt National Forests and is an equal opportunity service provider and employer.

Edited by: A. Petzold

\section{References}

Akimoto, H.: Global air quality and pollution, Science, 302, 17161718, 2003.

Anderson, T. L. and Ogren, J. A.: Determining aerosol radiative properties using the TSI 3563, intergrating nephelometer, Aerosol Sci. Technol., 29, 57-69, 1998.

Anderson, T. L., Covert, D. S., Marshall, S. F., Laucks, M. L., Charlson, R. J., Waggoner, A. P., Ogren, J. A., Caldow, R., Holm, R.L., Quant, F. R., Sem, G. J., Wiedensohler, A., Ahlquist, N. A., and Bates, T. S.: Performance characteristics of a high-sensitivity, three-wavelength, total scatter/backscatter nephelometer, J. Atmos. Oceanic Technol., 13, 967-986, 1996.

Aryal, R. P., Voss, K. J., Terman, P. A., Keene, W. C., Moody, J. L., Welton, E. J., and Holben, B. N.: Comparison of surface and column measurements of aerosol scattering properties over the western North Atlantic Ocean at Bermuda, Atmos. Chem. Phys., 14, 7617-7629, doi:10.5194/acp-14-7617-2014, 2014.

Asmi, A., Collaud Coen, M., Ogren, J. A., Andrews, E., Sheridan, P., Jefferson, A., Weingartner, E., Baltensperger, U., Bukowiecki, N., Lihavainen, H., Kivekäs, N., Asmi, E., Aalto, P. P., Kulmala, M., Wiedensohler, A., Birmili, W., Hamed, A., O'Dowd, C., G Jennings, S., Weller, R., Flentje, H., Fjaeraa, A. M., Fiebig, M., Myhre, C. L., Hallar, A. G., Swietlicki, E., Kristensson, A., and Laj, P.: Aerosol decadal trends - Part 2: In-situ aerosol particle number concentrations at GAW and ACTRIS stations, Atmos. Chem. Phys., 13, 895-916, doi:10.5194/acp-13-895-2013, 2013.

Augustine, J. A., Hodges, G. B., Dutton, E. G., Michalsky, J. J., and Cornwall, C. R.: An aerosol optical depth climatology for NOAA's national surface radiation budget network (SURFRAD), J. Geophys. Res., 113, D11204, doi:10.1029/2007JD009504, 2008.

Belnap, J. and Gillette, D. A.: Vulnerability of desert biological soil crusts to wind erosion: The influences of crust development, soil texture, and disturbance, J. Arid Environ., 39, 133-142, 1998.

Bigelow, D. S., Slusser, J. R., Beaubien, A. F., and Gibson, J. H.: The USDA ultraviolet radiation monitoring program, B. Am. Meteorol. Soc., 79, 601-615, 1998.

Bodhaine, B. A.: Aerosol measurements during the Mauna Loa Photochemistry Experiment 2, J. Geophys. Res., 101, 1475714766. 1996. 
Borys, R. D. and Wetzel, M. A.: Storm Peak Laboratory: A research, teaching and service facility for the atmospheric sciences, B. Am. Meteorol. Soc., 78, 2115-2123, 1997.

Boucher, O., Randall, D., Artaxo, P., Bretherton, C., G. Feingold, Forster, P., Kerminen, V.-M., Kondo, Y., Liao, H., Lohmann, U., Rasch, P., Satheesh, S.K., Sherwood, S., Stevens, B., and Zhang, X. Y.: Clouds and Aerosols. In: Climate Change 2013: The Physical Science Basis, Contribution of Working Group I to the Fifth Assessment Report of the Intergovernmental Panel on Climate Change, edited by: Stocker, T. F., Qin, D., Plattner, G.-K., Tignor, M., Allen, S. K., Boschung, J., Nauels, A., Xia, Y., Bex, V., and Midgley, P. M., Cambridge University Press, Cambridge, United Kingdom and New York, NY, USA, 2013.

Clarke, A. and Kapustin, V.: Hemispheric aerosol vertical profiles: Anthropogenic impacts on optical depth and cloud nuclei, Science, 329, 1488-1492, 2010.

Clarke, A., McNaughton, C., Kapustin, V., Shinozuka, Y., Howell, S., Dibb, J., Zhou, J., Anderson, B., Brekhovskikh, V., Turner, H., and Pinkerton, M.: Biomass burning and pollution aerosol over North America: Organic components and their influence on spectral optical properties and humidification response, J. Geophys. Res., 112, D12S18, doi:10.1029/2006JD007777, 2007.

Collaud Coen, M., Andrews, E., Asmi, A., Baltensperger, U., Bukowiecki, N., Day, D., Fiebig, M., Fjaeraa, A. M., Flentje, H., Hyvärinen, A., Jefferson, A., Jennings, S. G., Kouvarakis, G., Lihavainen, H., Lund Myhre, C., Malm, W. C., Mihapopoulos, N., Molenar, J. V., O'Dowd, C., Ogren, J. A., Schichtel, B. A., Sheridan, P., Virkkula, A., Weingartner, E., Weller, R., and Laj, P.: Aerosol decadal trends - Part 1: In-situ optical measurements at GAW and IMPROVE stations, Atmos. Chem. Phys., 13, 869894, doi:10.5194/acp-13-869-2013, 2013.

Cook, E. R., Woodhouse, C. A., Eakin, C. M., Meko, D. M., and Stahle, D. W.: Long-term aridity changes in the western United States, Science, 306, 1015-1018, 2004.

Creamean, J. M., Spackman, J. R., Davis, S. M., and White, A. B.: Climatology of long-range transported Asian dust along the West Coast of the United States, J. Geophys. Res.-Atmos., 119, 12$171,2014$.

Dennison, P. E., Brewer, S. C., Arnold, J. D., and Moritz, M. A.: Large wildfire trends in the western United States, 1984-2011, Geophys. Res. Lett., 41, 2928-2933, doi:10.1002/2014GL059576, 2014.

Draxler, R. R. and Rolph, G. D.: HYSPLIT (HYbrid SingleParticle Lagrangian Integrate Trajectory) Model access via NOAA ARL READY Website, available at: http://ready.arl.noaa. gov/HYSPLIT.php (last access: 5 August 2015), NOAA Air Resources Laboratory, Silver Spring, MD, 2015.

Dunlea, E. J., DeCarlo, P. F., Aiken, A. C., Kimmel, J. R., Peltier, R. E., Weber, R. J., Tomlinson, J., Collins, D. R., Shinozuka, Y., McNaughton, C. S., Howell, S. G., Clarke, A. D., Emmons, L. K., Apel, E. C., Pfister, G. G., van Donkelaar, A., Martin, R. V., Millet, D. B., Heald, C. L., and Jimenez, J. L.: Evolution of Asian aerosols during transpacific transport in INTEX-B, Atmos. Chem. Phys., 9, 7257-7287, doi:10.5194/acp-9-7257-2009, 2009.

Fischer, E. V., Hsu, N. C., Jaffe, D. A., Jeong, M.-J., and Gong, J. C.: A decade of dust: Asian dust and springtime aerosol load in the U.S. Pacific Northwest, Geophys. Res. Lett., 36, L03821, doi:10.1029/2008GL036467, 2009.
Gong, S. L., Zhang, X. Y, Zhao, T. L., McKendry, I. G., Jaffe, D. A., and Lu, N. M.: Characterization of soil dust aerosol in China and its transport/distribution during 2001 ACE-Asia 2. Model Simulation and Validation, J. Geophys. Res., 108, 4262, doi:10.1029/2002JD002633, 2003.

Hallar, A. G., Chirokova, G., McCubbin, I. B., Painter, T. H., Wiedinmyer, C., and Dodson, C.: Atmospheric Bioaerosols Transported Via Dust Storms in Western United States, Geophys. Res. Lett., 38, L17801, doi:10.1029/2011GL048166, 2011 a.

Hallar, A. G., Lowenthal, D. H., Chirokova, G., Wiedinmyer, C., and Borys, R. D.: Persistent Daily New Particle Formation at a Mountain-Top Location, Atmos. Environ., 45, 4111-4115, doi:10.1016/j.atmosenv.2011.04.044, 2011b.

J. L. Hand, Copeland, S. A., Day, D. E., Dillner, A. M., Indresand, H., Malm, W. C., McDade, C. E., Moore, C. T., Pitchford, M. L., Schichtel, B. A., and Watson, J. G.: IMPROVE (Interagency Monitoring of Protected Visual Environments): Spatial and seasonal patterns and temporal variability of haze and its constituents in the United States, Report V. CIRA Report ISSN: 0737-5352-87, available at: http://vista.cira.colostate.edu/ improve/Publications/Reports/2011/2011.htm (last access: 5 August 2015), 2011.

Hand, J. L., Schichtel, B. A., Malm, W. C., Copeland, S., Molenar, J. V., Frank, N., and Pitchford, M.: Widespread reductions in haze across the United States from the early 1990s through 2011, Atmos. Environ., 94, 671-679, 2014.

Harrison, L., Michalsky, J., and Berndt, J.: Automated multifilter rotating shadow-band radiometer: an instrument for optical depth and radiation measurements, Appl. Opt., 33, 5118-5125, 1994.

Heald, C. L., Jacob, D. J., Park, R. J., Alexander, B., Fairlie, T. D., Yantosca, R. M., and Chu, D. A.: Transpacific transport of Asian anthropogenic aerosols and its impact on surface air quality in the United States, J. Geophys. Res.-Atmos., 111, D14310, doi:10.1029/2005JD006847, 2006.

Huang, J., Guo, J., Wang, F., Liu, Z., Jeong, M. J., Yu, H., and Zhang, Z.: CALIPSO Inferred Most Probable Heights of Global Dust and Smoke Layers, J. Geophys. Res.-Atmos., 120, 50855100, doi:10.1002/2014JD022898, 2015.

Jaffe, D. A., Snow, J., and Cooper, O.: The 2001 Asian dust events: Transport and impact on surface aerosol concentrations in the US. Eos, Transactions American Geophysical Union, 84, 501507, 2003.

Kavouras, I. G., Etyemezian, V., Dubois, D. W., and Xu, J.: Source reconciliation of atmospheric dust causing visibility impairment in Class I areas of the western United States, J. Geophys. Res. 114, D02308, doi:10.1029/2008JD009923, 2009.

Kennedy, M. C. and Johnson, M. C.: Fuel treatment prescriptions alter spatial patterns of fire severity around the wildland-urban interface during the Wallow Fire, Arizona, USA, Forest Ecol. Manage., 318, 122-132, 2014.

Kiedron, P. W. and Michalsky, J. J.: Non-parametric and least squares Langley plot methods, Atmos. Meas. Tech. Discuss., 8, 4191-4218, doi:10.5194/amtd-8-4191-2015, 2015.

Landry, C. C., Buck, K. A., Raleigh, M. S., and Clark, M. P.: Mountain system monitoring at Senator Beck Basin, San Juan Mountains, Colorado: A new integrative data source to develop and evaluate models of snow and hydrologic processes, Water Resour. Res., 50, 1773-1788, doi:10.1002/2013WR013711, 2014. 
Leaitch, W. R., Macdonald, A. M., Anlauf, K. G., Liu, P. S. K., Toom-Sauntry, D., Li, S.-M., Liggio, J., Hayden, K., Wasey, M. A., Russell, L. M., Takahama, S., Liu, S., van Donkelaar, A., Duck, T., Martin, R. V., Zhang, Q., Sun, Y., McKendry, I., Shantz, N. C., and Cubison, M.: Evidence for Asian dust effects from aerosol plume measurements during INTEXB 2006 near Whistler, BC, Atmos. Chem. Phys., 9, 3523-3546, doi:10.5194/acp-9-3523-2009, 2009.

Lee, Y.-G. and Cho, C. H.: Characteristics of aerosol size distribution for a severe Asian dust event observed at Anmyeon, Korea in April 2006, J. Korean Meteor. Soc., 43, 87-96, 2007.

Lowenthal, D. H., Borys, R. D., and Wetzel, M. A.: Aerosol distributions and cloud interactions at a mountaintop laboratory, J. Geophys. Res., 107, 4345, doi:10.1029/2001JD002046, 2002.

Michalsky, J. and LeBaron, B.: Fifteen-year aerosol optical depth climatology for Salt Lake City, J. Geophys. Res. Atmos., 118, 3271-3277, doi:10.1002/jgrd.50329, 2013.

Michalsky, J. J., Schlemmer, J. A., Berkheiser, W. E., Berndt, J. L., Harrison, L. C., Laulainen, N. S., Larson, N. R., and Barnard, J. C.: Multiyear measurements of aerosol optical depth in the Atmospheric Radiation Measurement and Quantitative Links programs, J. Geophys. Res.-Atmos., 106, 12099-12107, 2001.

Michalsky, J., Denn, F., Flynn, C., Hodges, G., Kiedron, P., Koontz, A., and Schwartz, S. E.: Climatology of aerosol optical depth in north-central Oklahoma: 1992-2008, J. Geophys. Res.-Atmos., 115, D07203, doi:10.1029/2009JD012197, 2010.

Murphy, D. M., Chow, J. C., Leibensperger, E. M., Malm, W. C., Pitchford, M., Schichtel, B. A., Watson, J. G., and White, W. H.: Decreases in elemental carbon and fine particle mass in the United States, Atmos. Chem. Phys., 11, 4679-4686, doi:10.5194/acp-11-4679-2011, 2011.

Neff, J. C., Ballantyne, A. P., Farmer, G. L., Mahowald, N. M., Conroy, J., Landry, C. C., Overpeck, J., Painter, T. H., Lawrence, C. R., and Reynold, R.: Recent increases in eolian dust deposition due to human activity in the western United States, Nat. Geosci., 1, 189-195, doi:10.1038/ngeo133, 2008.

Obrist, D., Hallar, A. G., McCubbin, I., Stephens, B., and Rahn, T.: Atmospheric mercury concentrations at Storm Peak Laboratory in the Rocky Mountains: Evidence for long-range transport from Asia, boundary layer contributions, and plant mercury update, Atmos. Environ., 42, 7579-7589, 2008.

Painter, T. H., Barrett, A. P., Landry, C. C., Neff, J. C., Cassidy, M. P., Lawrence, C. R., McBride, K. E., and Farmer, G. L.: Impact of disturbed desert soils on duration of mountain snow cover, Geophys. Res. Lett., 34, L12502, doi:10.1029/2007GL030284, 2007.

Painter, T. H., Deems, J. S., Belnap, J., Hamlet, A. F., Landry, C. C., and Udall, B.: Response of Colorado River runoff to dust radiative forcing in snow, Proc. Natl. Acad. Sci. USA, 107, 1712517130, doi:10.1073/pnas.0913139107, 2010.

Painter, T. H., Bryant, A. C., and Skiles, S. M.: Radiative forcing by light absorbing impurities in snow from MODIS surface reflectance data, Geophys. Res. Lett., 39, L17502, doi:10.1029/2012GL052457, 2012.

A. Papayannis, Zhang, H. Q., Amiridis, V., Ju, H. B., Chourdakis, G., Georgoussis, G., Pérez, C., Chen, H. B., Goloub, P., Mamouri, R. E., Kazadzis, S., Paronis, D., Tsaknakis, G., and Baldasano, J. M.: Extraordinary dust event over Beijing, China, during April 2006: Lidar, Sun photometric, satellite observa- tions and model validation, Geophys. Res. Lett., 34, L07806, doi:10.1029/2006GL029125, 2007.

Reynolds, R., Belnap, J., Reheis, M., Lamothe, P., and Luiszer, F.: Aeolian dust in Colorado Plateau soils: Nutrient inputs and recent change in source, Proc. Natl. Acad. Sci. USA, 98, 71237127, 2001.

Russell, P. B., Bergstrom, R. W., Shinozuka, Y., Clarke, A. D., DeCarlo, P. F., Jimenez, J. L., Livingston, J. M., Redemann, J., Dubovik, O., and Strawa, A.: Absorption Angstrom Exponent in AERONET and related data as an indicator of aerosol composition, Atmos. Chem. Phys., 10, 1155-1169, doi:10.5194/acp-101155-2010, 2010.

Schoennagel, T., Veblen, T. T., and Romme, W. H.: The interaction of fire, fuels, and climate across Rocky Mountain forests, BioScience, 54, 661-676, 2004.

Seager, R., Ting, M., Held, I., Kushnir, Y., Lu, J., Vecchi, G., and Naik, N.: Model projections of an imminent transition to a more arid climate in southwestern North America, Science, 316, 11811184, 2007.

Seinfeld, J. H., Carmichael, G. R., Arimoto, R., Conant, W. C., Brechtel, F. J., Bates, T. S., Cahill, T. A., Clarke, A. D., Doherty, S. J., Flatau, P. J., Huebert, B. J., Kim, J., Markowicz, K. M., Quinn, P. K., Russell, L. M., Russell, P. B., Shimizu, A., Shinozuka, Y., Sonv, C. H., Tang, Y., Uno, I., Vogelmann, A. M., Weber, R. J., Woo, J.-H., and Zhang, X. Y.: ACE-ASIA: Regional climatic and atmospheric chemical effects of Asian dust and pollution, B. Am. Meteorol. Soc., 85, 367-380, 2004.

Sheridan, P. J., Jefferson, A., and Ogren, J. A.: Spatial variability of submicrometer aerosol radiative properties over the Indian Ocean during INDOEX, J. Geophys. Res., 107, doi:10.1029/2000JD000166, 2002.

Skiles, S. M., Painter, T. H., Deems, J. S., Bryant, A. C., and Landry, C.: Dust radiative forcing in snow of the Upper Colorado River Basin: Part II. Interannual variability in radiative forcing and snowmelt rates, Water Resour. Res., 48, doi:10.1029/2012WR011986, 2012.

Spracklen, D. V., Mickley, L. J., Logan, J. A., Hudman, R. C., Yevich, R., Flannigan, M. D., and Westerling, A. L.: Impacts of climate change from 2000 to 2050 on wildfire activity and carbonaceous aerosol concentrations in the western United States, J. Geophys. Res., 114, D20301, doi:10.1029/2008JD010966, 2009.

Sun, Y., Zhang, Q., Macdonald, A. M., Hayden, K., Li, S. M., Liggio, J., Liu, P. S. K., Anlauf, K. G., Leaitch, W. R., Steffen, A., Cubison, M., Worsnop, D. R., van Donkelaar, A., and Martin, R. V.: Size-resolved aerosol chemistry on Whistler Mountain, Canada with a high-resolution aerosol mass spectrometer during INTEX-B, Atmos. Chem. Phys., 9, 3095-3111, doi:10.5194/acp9-3095-2009, 2009.

Thulasiraman, S., O’Neill, N. T., Royer, A., Holben, B. N., Westphal, D. L., and McArthur, L. J. B.: Sunphotometric observations of the 2001 Asian dust storm over Canada and the U.S., Geophys. Res. Lett., 29, 96-1. doi:10.1029/2001GL014188, 2002.

Toledano, C., Cachorro, V. E., Berjon, A., De Frutos, A. M., Sorribas, M., De la Morena, B. A., and Goloub, P.: Aerosol optical depth and Angstrom exponent climatology at El Arenosillo AERONET site (Huelva, Spain), Q. J. R. Meteorol. Soc., 133, 795-807, 2007.

Tong, D. Q., Dan, M., Wang, T., and Lee, P.: Long-term dust climatology in the western United States reconstructed from routine 
aerosol ground monitoring, Atmos. Chem. Phys., 12, 5189-5205, doi:10.5194/acp-12-5189-2012, 2012.

United States Environmental Protection Agency (U.S. EPA): Guidance for Estimating Natural Visibility Conditions Under the Regional Haze Rule, EPA 454/B-03-005, Office of Air Qual. Planning and Stand., Research Triangle Park, N.C., 2003.

Uno, I., Eguchi, K., Yumimoto, K., Takemura, T., Shimizu, A., Uematsu, M., Liu, Z., Wang, Z., Hara, Y., and Sugimoto, N.: Asian dust transported one full circuit around the globe, Nat. Geosci., 2, 557-560, 2009.

VanCuren, R. and Cahill, T.: Asian aerosols in North America: Frequency and concentration of fine dust, J. Geophys. Res., 107, 4804, doi:10.1029/2002JD002204, 2002.

VanCuren, R. A., Cliff, S. S., Perry, K. D., and Jimenez-Cruz, M.: Asian continental aerosol persistence above the marine boundary layer over the eastern North Pacific: Continuous aerosol measurements from Intercontinental Transport and Chemical Transformation 2002 (ITCT 2K2), J. Geophys. Res., 110, D09S90, doi:10.1029/2003JD003459, 2005.

Val Martin, M., Heald, C. L., Ford, B., Prenni, A. J., and Wiedinmyer, C.: A decadal satellite analysis of the origins and impacts of smoke in Colorado, Atmos. Chem. Phys., 13, 74297439, doi:10.5194/acp-13-7429-2013, 2013.
Val Martin, M., Heald, C. L., Lamarque, J.-F., Tilmes, S., Emmons, L. K., and Schichtel, B. A.: How emissions, climate, and land use change will impact mid-century air quality over the United States: a focus on effects at national parks, Atmos. Chem. Phys., 15, 2805-2823, doi:10.5194/acp-15-2805-2015, 2015.

Watson, J. G.: Visibility: Science and Regulation, J. Air Waste Manage. Assoc., 52, 628-713, doi:10.1080/10473289.2002.10470813, 2002.

Wells, K. C., Witek, M., Flatau, P., Kreidenweiß, S. M., and Westphal, D. J.: An analysis of seasonal surface dust concentrations in the western US (2001-2004): Observations and model predictions, Atmos. Environ., 41, 6585-6597, 2007.

Westerling, A. L., Hidalgo, H. G., Cayan, D. R., and Swetnam, T. W.: Warming and earlier spring increase western US forest wildfire activity, Science, 313, 940-943, 2006.

Yu, H., Remer, L. A., Chin, M., Bian, H., Kleidman, R. G., and Diehl, T.: A satellite-based assessment of transpacific transport of pollution aerosol, J. Geophys. Res.-Atmos., 113, D14S12, doi:10.1029/2007JD009349, 2008.

Yu, H., Remer, L. A., Chin, M., Bian, H., Tan, Q., Yuan, T., and Zhang, Y.: Aerosols from overseas rival domestic emissions over North America, Science, 337, 566-569, 2012. 